\title{
New vaccine administration practice recommendations from the Canadian Immunization Guide
}

\author{
C Jensen ${ }^{1}$, D Moore ${ }^{2}, \mathrm{C} \mathrm{Mah}^{3}$, O Baclic ${ }^{1}$, S Marchant-Short ${ }^{4}$ on behalf of the National Committee \\ on Immunization (NACl)*
}

\begin{abstract}
Background: The Canadian Immunization Guide (CIG) is published online by the Public Health Agency of Canada and summarizes guidance on vaccines for human use into a single resource. Chapters are reviewed and updated on a regular basis. Vaccine administration is a critical part of any immunization program. Recently, the CIG chapter on vaccine administration practices was updated.
\end{abstract}

Objective: To provide highlights of recent changes to the Vaccine Administration Practices chapter of the CIG.

Approach: Vaccine-specific guidance in the CIG is based on National Committee on Immunization (NACl) and Committee to Advise on Tropical Medicine and Travel (CATMAT) recommendations as well as new recommendations developed by the CIG Working Group members and $\mathrm{NACl}$ Secretariat technical staff. New recommendations are based on a review of the literature, including systematic reviews when available, a review of guidance provided by other National Immunization Technical Advisory Groups and expert opinion. The revisions are approved by the Working Group chair, as well as NACl.

Results: Highlights of new recommendations include the following: vaccine providers should adhere to jurisdictional or organizational policies and procedures regarding combining the contents of multi-dose vials; clinical judgement should be used when selecting needle length for intramuscular injections that takes into account the vaccine recipient's weight, gender and age; filter needles are not recommended for vaccine administration as they may filter out active ingredients such as adjuvants; an injection site other than in an area where lymphatic drainage may be impaired should be considered; there is no evidence or theoretical rationale for avoiding injection through a tattoo or superficial birthmark; and immunization pain management strategies have now been developed for all ages.

Conclusion: Recommendations in vaccine administration practices have recently been changed in some important ways. The Public Health Agency of Canada is committed to providing information on immunization in an easily accessible, reader-friendly format for healthcare providers and policy-makers.

\author{
Affiliations \\ ${ }^{1}$ Centre for Immunization and \\ Respiratory Infectious Diseases, \\ Public Health Agency of Canada, \\ Ottawa, ON \\ ${ }^{2}$ McGill University, Montreal, QC \\ ${ }^{3}$ Dalhousie University, Halifax, \\ NS and University of Toronto, \\ Toronto, ON \\ ${ }^{4}$ Public Health Nursing, Health \\ PEI, Charlottetown, PE
}

*Correspondence: naci-ccni@ phac-aspc.gc.ca

Suggested citation: Jensen C, Moore D, Mah C, Baclic O, Marchant-Short S on behalf of the National Committee on Immunization (NACl). New vaccine administration practice recommendations from the Canadian Immunization Guide. Can Commun Dis Rep. 2017;43(11):242-4. https://doi.org/10.14745/ccdr.v43i11a06

\section{Introduction}

The Canadian Immunization Guide (CIG) is published online by the Public Health Agency of Canada (PHAC). It is a trusted, reader-friendly summary of information on immunization and has been used by healthcare providers who administer vaccines to their patients and by policy-makers for the delivery of immunization programs since 1979 (1). The CIG is divided into five parts and summarizes guidance from the National Advisory Committee on Immunization (NACl) and the Committee to
Advise on Tropical Medicine and Travel (CATMAT) into a single resource. Chapters are reviewed and updated on a four year cycle or more frequently in the event of a new recommendation or a changing practice. A Table of Updates (2) summarizes key changes as they are made to individual chapters.

Vaccine administration is a critical part of any immunization program. Important considerations in vaccine administration practices are pre-vaccination counselling, vaccine preparation and needle selection, as well as identification of the proper route, site and technique for vaccine administration. 
Immunization pain management strategies, postvaccination counselling and observation and infection prevention and control are also integral parts of vaccine administration practices. The objective of this article is to provide highlights of the key changes to the Vaccine Administration Practices chapter in Part 1 of the CIG.

\section{Approach}

Vaccine-specific guidance in the CIG is summarized from $\mathrm{NACl}$ and CATMAT recommendations as written in the statements and updates $(3,4)$. New recommendations not contained in a $\mathrm{NACl}$ or CATMAT statement are written by the CIG Working Group members and NACI Secretariat technical staff at PHAC. The revisions are approved by the Working Group chair, as well as $\mathrm{NACl}$. The Part 1 Working Group was activated to revise the Vaccine Administration Practices chapter in August 2016. The previous version of the Vaccine Administration Practices chapter was published online in 2014. A chapter revision was undertaken prior to the four year cycle as there was new research, particularly in the areas of needle selection and pain management, which prompted a chapter revision.

A full chapter revision was undertaken. Feedback on the existing chapter was solicited by the NACl Liaison Member of the Canadian Immunization Committee from nurse immunizers. Requests for clarification and guidance were considered and the chapter was reviewed to identify issues that required a review of the literature. The revised needle length recommendations provided in "Table 3: Needle selection guidelines" of the Vaccine Administration Practices chapter were based on a review of the literature, a review of guidance provided by other National Immunization Technical Advisory Groups (NITAGs) and expert opinion. The revised recommendations in "Table 4: Immunization pain management strategies, by age groups" of the Vaccine Administration Practices chapter were based on the systematic review of vaccine injection pain reduction strategies by Taddio and colleagues (5). The six systematic reviews, upon which the guidelines were based, were assessed using the Assessing the Methodological Quality of Systematic Reviews (AMSTAR) checklist by the $\mathrm{NACl}$ Secretariat prior to inclusion in the chapter revision (6).

Table 1: Key changes to Vaccine Administration Practices chapter

\begin{tabular}{|c|c|c|c|}
\hline Topic & $\begin{array}{c}\text { Section } \\
\text { Heading - } \\
\text { Sub-heading }\end{array}$ & $\begin{array}{l}\text { Previous } \\
\text { guidance }\end{array}$ & $\begin{array}{c}\text { Revised/new } \\
\text { guidance }\end{array}$ \\
\hline $\begin{array}{l}\text { Combination } \\
\text { of contents } \\
\text { of multi-dose } \\
\text { vials }\end{array}$ & $\begin{array}{l}\text { Vaccine } \\
\text { administration } \\
\text { - Vaccine } \\
\text { preparation } \\
\text { - Vaccine } \\
\text { inspection and } \\
\text { mixing }\end{array}$ & $\begin{array}{l}\text { In immunization } \\
\text { clinics in which } \\
\text { only a single } \\
\text { vaccine is being } \\
\text { administered, } \\
\text { the contents } \\
\text { of more than } \\
\text { one multi-dose } \\
\text { vial may be } \\
\text { combined to } \\
\text { prevent wastage } \\
\text { if the vials have } \\
\text { the same lot } \\
\text { number. }\end{array}$ & $\begin{array}{l}\text { Vaccine providers } \\
\text { should adhere } \\
\text { to jurisdictional } \\
\text { or organizational } \\
\text { policies and } \\
\text { procedures } \\
\text { regarding } \\
\text { combining the } \\
\text { contents of multi- } \\
\text { dose vials. }\end{array}$ \\
\hline
\end{tabular}

Table 1: Key changes to Vaccine Administration Practices chapter (continued)

\begin{tabular}{|c|c|c|c|}
\hline Topic & $\begin{array}{c}\text { Section } \\
\text { Heading - } \\
\text { Sub-heading }\end{array}$ & $\begin{array}{l}\text { Previous } \\
\text { guidance }\end{array}$ & $\begin{array}{c}\text { Revised/new } \\
\text { guidance }\end{array}$ \\
\hline $\begin{array}{l}\text { Needle } \\
\text { selection for } \\
\text { intramuscular } \\
\text { injections (IM) }\end{array}$ & $\begin{array}{l}\text { Vaccine } \\
\text { administration } \\
\text { - Needle } \\
\text { selection } \\
\text { - Table 3: Needle } \\
\text { selection } \\
\text { guidelines } \\
\text { - Route of } \\
\text { administration, } \\
\text { Intramuscular } \\
\text { (IM) }\end{array}$ & $\begin{array}{l}\text { Needle length: } \\
2.2-2.5 \mathrm{~cm} \\
(7 / 8-1 \text { inch) for } \\
\text { infants, toddlers } \\
\text { and older } \\
\text { children } \\
2.5-3.8 \mathrm{~cm} \\
(1-11 / 2 \text { inches }) \\
\text { for adolescents } \\
\text { and adults }\end{array}$ & $\begin{array}{l}\text { A range of needle } \\
\text { lengths are } \\
\text { provided in the } \\
\text { revised Table 3, as } \\
\text { clinical judgement } \\
\text { should be used } \\
\text { when selecting } \\
\text { needle length } \\
\text { for IM injections. } \\
\text { Consideration } \\
\text { should be given } \\
\text { to the vaccine } \\
\text { recipient's weight, } \\
\text { gender and age }\end{array}$ \\
\hline $\begin{array}{l}\text { Use of } \\
\text { filtration } \\
\text { needles }\end{array}$ & $\begin{array}{l}\text { Vaccine } \\
\text { administration } \\
\text { - Needle } \\
\text { selection }\end{array}$ & None & $\begin{array}{l}\text { Filtration } \\
\text { needles are not } \\
\text { recommended } \\
\text { for vaccine } \\
\text { administration as } \\
\text { they may filter out } \\
\text { active ingredients } \\
\text { such as adjuvants }\end{array}$ \\
\hline $\begin{array}{l}\text { Vaccine } \\
\text { administration } \\
\text { into an } \\
\text { area where } \\
\text { lymphatic } \\
\text { circulation } \\
\text { may be } \\
\text { impaired } \\
\text { or through } \\
\text { a tattoo or } \\
\text { superficial } \\
\text { birthmark }\end{array}$ & $\begin{array}{l}\text { Vaccine } \\
\text { administration } \\
\text { - Route, site } \\
\text { and technique } \\
\text { for vaccine } \\
\text { administration } \\
\text { - Parenteral } \\
\text { vaccines }\end{array}$ & None & $\begin{array}{l}\text { Injection of a } \\
\text { vaccine into } \\
\text { an area where } \\
\text { lymphatic } \\
\text { circulation may } \\
\text { be impaired (e.g., } \\
\text { local lymphedema, } \\
\text { lymphangioma, } \\
\text { axillary lymph } \\
\text { node dissection, } \\
\text { arteriovenous (A- } \\
\text { V) fistula, upper } \\
\text { limb amputation) } \\
\text { could theoretically } \\
\text { result in an } \\
\text { impaired immune } \\
\text { response due to } \\
\text { impaired vaccine } \\
\text { absorption, } \\
\text { although there are } \\
\text { no data to support } \\
\text { this. Consider } \\
\text { an alternative } \\
\text { injection site if } \\
\text { possible. There } \\
\text { is no evidence } \\
\text { or theoretical } \\
\text { rationale for } \\
\text { avoiding injection } \\
\text { through a tattoo } \\
\text { or superficial } \\
\text { birthmark }\end{array}$ \\
\hline $\begin{array}{l}\text { Techniques } \\
\text { to decrease } \\
\text { immunization } \\
\text { injection pain }\end{array}$ & $\begin{array}{l}\text { Vaccine } \\
\text { administration } \\
\text { - Techniques } \\
\quad \text { to decrease } \\
\quad \text { immunization } \\
\quad \text { injection pain } \\
\text { Table 4: } \\
\text { Immunization } \\
\text { pain management } \\
\text { strategies, by age } \\
\text { groups }\end{array}$ & $\begin{array}{l}\text { The previous } \\
\text { version of Table } \\
4 \text { contained only } \\
\text { immunization } \\
\text { pain management } \\
\text { strategies for } \\
\text { children }\end{array}$ & $\begin{array}{l}\text { Revised version of } \\
\text { Table } 4 \text { provides } \\
\text { immunization } \\
\text { pain management } \\
\text { strategies for all } \\
\text { ages }\end{array}$ \\
\hline
\end{tabular}




\section{Summary of updates}

The updates are summarized in Table 1. For complete information, please refer to the Vaccine Administration Practices chapter in the CIG (7).

\section{Discussion}

Recommendations in vaccine administration practices have changed recently in some important ways; vaccine providers in Canada should consult jurisdictional or organizational policies regarding the combination of contents of multi-dose vials. Now vaccine providers are encouraged to take weight, gender and age into consideration in the selection of needle length for intramuscular injections. Additionally, there are now pain management strategies to decrease injection pain for all ages. These new recommendations may inform upcoming vaccination campaigns in terms of vaccine administration practices.

The Public Health Agency of Canada is committed to providing information on immunization and vaccines available for use in Canada in an easily accessible, reader-friendly format, through timely and ongoing CIG updates. To receive information regarding new $\mathrm{NACl}$ recommendations, statements and updates and/or updates to $\mathrm{CIG}$ chapters, please subscribe to the mailing list (8).

\section{Authors' statement}

This report summary was prepared by the CIG Part 1 Working Group: Marchant-Short S (Chair), Moore D, Mah C, Jensen C and Baclic O. Marchant-Short $\mathrm{S}$ is a $\mathrm{NACl}$ member. Moore $\mathrm{D}$ and Mah $\mathrm{C}$ are $\mathrm{NACl}$ Liaison members.

\section{Conflict of interest}

None.

\section{Acknowledgements}

The authors would like to thank the extremely dedicated $\mathrm{NACl}$ members and the staff of Public Health Agency of Canada who support the Canadian Immunization Guide process.

\section{Funding}

The Public Health Agency of Canada supports the activities of $\mathrm{NACl}$ as an external advisory body.

\section{References}

1. Government of Canada. Canadian Immunization Guide. Ottawa ON: PHAC. https://www.canada.ca/en/public-health/ services/canadian-immunization-guide.html [Accessed September 8, 2017].

2. Government of Canada. Canadian Immunization Guide: Table of Updates. Ottawa ON. https://www.canada.ca/ en/public-health/services/canadian-immunization-guide/ updates.html [Accessed September 8, 2017].

3. Government of Canada. National Advisory Committee on Immunization. Ottawa ON: PHAC. https://www.canada.ca/ en/public-health/services/immunization/national-advisorycommittee-on-immunization-naci.html [Accessed September 8, 2017].

4. Government of Canada. About CATMAT. Ottawa ON: PHAC. https://www.canada.ca/en/public-health/services/travelhealth/about-catmat.html [Accessed September 8, 2017].

5. Taddio A, McMurtry CM, Shah V, Riddell RP, Chambers CT, Noel M, MacDonald NE, Rogers J, Bucci LM, Mousmanis P, Lang E, Halperin SA, Bowles S, Halpert C, Ipp M, Asmundson GJG, Rieder MJ, Robson K, Uleryk E, Antony MM, Dubey V, Hanrahan A, Lockett D, Scott J, Bleeker EV; HELPinKIDS\&Adults. Reducing pain during vaccine injections: clinical practice guideline. CMAJ 2015; 187(13):975-82. DOI (http://dx.doi.org/10.1503/ cmaj.150391). PubMed (https://www.ncbi.nlm.nih.gov/ entrez/query.fcgi?cmd=Retrieve\&db=PubMed\&list_ uids $=26303247 \&$ dopt=Abstract).

6. Shea BJ, Grimshaw JM, Wells GA, Boers M, Andersson N, Hamel C, Porter AC, Tugwell P, Moher D, Bouter LM. Development of AMSTAR: a measurement tool to assess the methodological quality of systematic reviews. BMC Medical Research Methodology. 2007;7(10):1-7. DOI (https://doi. org/10.1186/1471-2288-7-10). PubMed (https://www.ncbi. $\mathrm{nlm}$.nih.gov/entrez/query.fcgi?cmd=Retrieve\&db=PubMed\&l ist_uids=17302989\&dopt=Abstract).

7. Government of Canada. Canadian Immunization Guide: Vaccine Administration Practices. Ottawa ON. https:// www.canada.ca/en/public-health/services/publications/ healthy-living/canadian-immunization-guide-part-1-keyimmunization-information/page-8-vaccine-administrationpractices.html [Accessed September 8, 2017].

8. Government of Canada. Canadian Immunization Guide Update - Mailing List. Ottawa ON. http:// www.healthycanadians.gc.ca/healthy-living-viesaine/immunization-immunisation/canadianimmunization-guide-canadien-immunisation/ email-subscription-abonnement-courriel-eng. php?_ga=2.266822922.504025174.1504710542950076339.1489780715 [Accessed September 8, 2017]. 